\title{
Current Developments in Antithrombotic Therapy: The Role of Antithrombin Agents
}

\author{
H.K. Breddin \\ International Institute of Thrombosis and Vascular Diseases e.V., Frankfurt, Germany
}

\section{Key Words}

Thrombin inhibitors · Hirudin · Hirulog • PEG-hirudin • Argatroban · Inogatran - Melagatran · Heparin-induced thrombocytopenia

\begin{abstract}
Hirudin, the specific thrombin inhibitor from medicinal leeches, is now produced by recombinant technology. $r$ Hirudin and to a lesser extent polyethyleneglycol-coupled hirudin (PEG-hirudin) have been used in many clinical trials. Hirudin has been shown to be more effective than low molecular weight heparin in the prevention of deep venous thrombosis after total hip replacement. In (acute) coronary syndromes hirudin as well as a synthetic hirudin analogue bivalirudin have been studied in large clinical trials. Higher doses of hirudin were associated with an increased risk of bleeding. A large-scale study with bivalirudin in patients with acute MI (the HERO-2 trial) has not shown a reduction in mortality but a $30 \%$ reduction of reinfarction within $96 \mathrm{~h}$. Hirudin and argatroban have been successfully used in patients with heparin-induced thrombocytopenia type II. Several orally active thrombin inhibitors are being developed. The combined use of subcutaneous and oral administration of melagatran in patients with hip or knee replacement has led to promising results. It is likely that in the future thrombin inhibitors will replace other forms of anticoagulation in a number of indications.
\end{abstract}

Copyright $\odot 2002$ S. Karger AG, Basel

\begin{tabular}{ll}
\hline KARGER & (c) 2002 S. Karger AG, Basel \\
1424-8832/02/0329-0001\$18.50/0 \\
$\begin{array}{l}\text { Fax +4161306 1234 } \\
\begin{array}{l}\text { E-Mail karger@karger.ch } \\
\text { www.karger.com }\end{array}\end{array}$ & $\begin{array}{l}\text { Accessible online at: } \\
\text { www.karger.com/pht }\end{array}$
\end{tabular}

\section{Introduction}

During the last 20 years, low molecular weight heparins have replaced unfractionated heparin (UFH) in many indications. UFH has a similar effect on thrombin and the coagulation factor $\mathrm{Xa}$, but heparins are not direct inhibitors of thrombin and factor $\mathrm{Xa}$. They activate the plasma proteins antithrombin and heparin co-factor II, and this mechanism leads to their anticoagulant effects. Heparins have been used for 40 years in the prophylaxis and treatment of venous or arterial thromboses; improvements in therapy may be anticipated from direct thrombin or factor Xa inhibitors. Specific thrombin inhibitors are independent of the plasma level of antithrombin and of the inactivation of thrombin by heparin cofactor II.

Thrombin plays a central role in regulating thrombotic processes. It is a glycosylated, trypsin-like proteinase, which is formed out of prothrombin by the prothrombinase complex (factors $\mathrm{Xa}, \mathrm{Va}$, calcium and phospholipids).

Thrombin influences the permeability of platelet membranes, it has direct effects on the vascular endothelium and many other actions on different cell systems, including the stimulation of synthesis and release of mediators from vascular endothelium. After the characterization of the first specific thrombin inhibitor hirudin by Fritz Markwardt, many other thrombin inhibitors have been detected in different haematophagus animals [1]. Today hirudin is produced by recombinant technology

\footnotetext{
Prof. Dr. H.K. Breddin

International Institute of Thrombosis and Vascular Diseases e.V

Ferdinand-Schrey-Weg 6

D-60598 Frankfurt am Main (Germany)

Tel. +4969 637964, Fax +4969 63152220, E-Mail Breddin@em.uni-frankfurt.de
} 
and new inhibitors are synthetized. Low molecular weight thrombin inhibitors have been developed later on.

Hirudin and other thrombin inhibitors have been studied in a number of clinical trials and at present several oral thrombin inhibitors are being developed by different pharmaceutical companies.

\section{Parenteral Thrombin Inhibitors}

\section{Hirudin}

Hirudin is a specific thrombin inhibitor which was originally obtained from the salivary glands of the medicinal leech (Hirudo medicinalis). It was first isolated and characterized by Markwardt [2] in 1957. For approximately 20 years, hirudin has been produced by recombinant technology (r-hirudin). r-Hirudins are as active and specific as natural hirudin. r-Hirudin and a polyethyleneglycol-coupled hirudin (PEG-hirudin) have been investigated in clinical trials in different indications. Hirudin and r-hirudin have a molecular weight of 7,000 D. The molecular weight of PEG-hirudin is 17,000 D. Hirudinderived molecules, such as hirulog, have been used in different clinical trials $[3,4]$.

Methods for the Monitoring of Hirudin and Other

Thrombin Inhibitors

The measurement of the thrombin-inhibiting effect (anti-F-IIa-activity) in plasma using a chromogenic substrate is probably the most precise method to monitor prophylaxis or treatment with hirudin. However, the ecarin time is simpler, more practical and especially suited for bedside monitoring $[5,6]$. The ecarin clotting time (ECT) is well correlated with the inhibition of thrombin as it is measured using chromogenic substrates. Other methods including the activated partial thromboplastin time (aPTT) and the activated clotting time (ACT) can also be used to monitor the effect of thrombin inhibitors. These methods, however, are not specific and are modified by acquired and inborn coagulation defects and in addition they are not well standardized. The thrombin time is too sensitive and therefore less suited for the control of thrombin inhibitors [7].

\section{Hirudin in Coronary Heart Disease}

Large clinical trials with r-hirudin in patients with unstable angina [8], patients with acute myocardial infarctions or acute coronary syndromes [9-13] and after coronary angioplasty [14] have been published.
In the two largest studies (GUSTO 2a and TIMI 9a), a relatively high initial intravenous bolus of $0.6 \mathrm{mg} / \mathrm{kg}$ hirudin was followed by a continuous infusion of $0.2 \mathrm{mg} / \mathrm{kg} / \mathrm{h}$ [9, 12]. All patients received aspirin and many were also treated with thrombolytic agents. Both studies were stopped because of increased intracranial bleedings, and in the GUSTO 2a study increased mortality had been observed in the hirudin arms. In the TIMI 9a study, there were $14 \%$ major bleedings in the hirudin group compared to $10 \%$ in the heparin group.

Both studies were restarted with a much lower initial intravenous bolus of $0.1 \mathrm{mg} / \mathrm{kg}$ followed by an intravenous infusion $0.1 \mathrm{mg} / \mathrm{kg} / \mathrm{h}$. Following this change, bleeding complications under hirudin were not more frequent than in the heparin group. The clinical efficacy was equivalent to or minimally better than that of heparin $[15,16]$.

In further studies [17-19], another recombinant hirudin (HBW 023) was used in patients with acute myocardial infarcts together with streptokinase. The patients received either hirudin (i.v. bolus of $0.2 \mathrm{mg} / \mathrm{kg}$, followed by $0.5 \mathrm{mg} / \mathrm{kg} / \mathrm{h}$ as continuous infusion) or UFH. There were no significant differences in either efficacy or bleeding complications between the two treatment groups. It is possible that the observed hemorrhagic complications in the studies with higher hirudin doses were partially caused by the concomitant use of aspirin.

\section{Interactions of Hirudin and Aspirin}

We compared the effect of PEG-hirudin and aspirin alone with a combination of PEG-hirudin and aspirin in healthy volunteers [20]. A mean hirudin level of $1.8 \mu \mathrm{g} / \mathrm{ml}$ was achieved. The bleeding time was minimally prolonged under PEG-hirudin, slightly prolonged under aspirin but very much prolonged in volunteers who received $300 \mathrm{mg}$ aspirin + PEG-hirudin. The effect of the combination was more than additive. We cannot yet explain what causes this synergistic effect of a combination of hirudin and aspirin.

Similar interaction studies with heparin and aspirin have shown that the combined use leads to prolongation of the bleeding time but only to a slight additive effect [21].

Hirudin in the Prophylaxis and Treatment of Deep

Venous Thrombosis

Hirudin has been more effective than UFH in the prophylaxis of thrombosis after total hip replacement [22]. In another large study [23], recombinant hirudin $(2 \times$ $15 \mathrm{mg}$ /day s.c.) was compared with the low molecular weight heparin enoxaparin (once daily $40 \mathrm{mg}$ s.c.). Enoxa- 
parin was administered to 1,023 patients and hirudin to 1,028 patients. The thrombosis rate in the enoxaprin group was $28.5 \%$ and $18.4 \%$ in the hirudin group; hirudin reduced the incidence of proximal thrombosis $(7.5 \%$ in the enoxaparin group, $4.5 \%$ in the hirudin group). The difference was statistically significant. r-Hirudin was more effective than low molecular weight heparin in this high-risk population. Hirudin has been approved for this indication.

There are few data on the treatment of acute deep venous thrombosis with hirudin [24, 25]. In this indication, low molecular weight heparins probably are more suitable, and their effect has been established in many clinical trials. Moreover, at higher doses hirudin probably needs laboratory monitoring.

\section{Possible Further Development of Hirudin and}

\section{PEG-Hirudin}

r-Hirudin and PEG-hirudin are being investigated in new trials in patients with unstable angina. It is expected that PEG-hirudin, because of its longer half-life, will reduce the amount of hirudin needed and will also lead to more stable plasma levels.

In patients with renal insufficiency there is a risk of overdosing because the elimination of hirudin is considerably impaired.

Hirudin can be used instead of UFH in cardiopulmonary bypass. Many cardiac surgeons are concerned about heparin-induced thrombocytopenia (HIT) in patients who have had prior heparin exposure. This risk does not exist with hirudin and in some centers hirudin is successfully used instead of UFH for the anticoagulation in combination with extracorporeal circulation.

\section{Bivalirudin}

Bivalirudin (hirulog) was compared with UFH in several studies in patients undergoing PTCA in acute coronary syndromes and has shown increased efficacy and reduced bleeding risk in both indications [3, 26-31]. Bivalirudin at a dose of $1 \mathrm{mg} / \mathrm{kg}$ every $8 \mathrm{~h}$ was effective in a dose-finding study on the prevention of thromboses after major hip or knee surgery [32].

In a recent study (HERO acute MI study) bivalirudin, given as an intravenous bolus of $0.2 \mathrm{mg} / \mathrm{kg}$, followed by $0.5 \mathrm{mg} / \mathrm{kg} / \mathrm{h}$ for $12 \mathrm{~h}$ and $0.2 \mathrm{mg} / \mathrm{kg} / \mathrm{h}$ up to $60 \mathrm{~h}$, led to an increased TIMI grade 3 coronary flow in a higher percentage of patients and to a reduced incidence of death, MI and cardiogenic shock compared to UFH [33].

In the large HERO 2 trial in 17,000 patients with acute MI bivalirudin has been compared with UFH [33]. Bivali- rudin did not reduce mortality compared with UFH but reduced reinfarction by $30 \%$ within $96 \mathrm{~h}$. There was a slight increase in mild and moderate bleeding in patients treated with bivalirudin.

\section{Argatroban}

Argatroban is a synthetic direct thrombin inhibitor derived from $L$-arginine and was initially developed by Mitsubishi Chemical Industries. In Japan, the drug is approved for Buerger's disease, arteriosclerosis obliterans, acute cerebral thrombosis and anticoagulation of antithrombin-III-deficient patients undergoing hemodialysis. The use of argatroban in Japan will be discussed later in this issue.

Argatroban is excreted through the liver and therefore does not accumulate in renally impaired patients. Argatroban can be monitored using aPTT. Argatroban is a less potent inhibitor of thrombin than lepirudin, but this fact is associated with a (probably) larger therapeutic window. Argatroban will not produce antibodies and therefore long-term and repeat treatments are possible. Argatroban can easily be monitored [34].

Preliminary studies have shown successful use of argatroban for anticoagulation during percutaneous coronary intervention in HIT II-patients without excessive bleeding [35-40].

\section{Inogatran}

Inogatran is a low molecular weight specific thrombin inhibitor that has been investigated in patients with myocardial ischemia (TRIM study). In this study, inogatran was administered intravenously; no advantage in comparison to UFH could be demonstrated [41]. After stopping the inogatran infusion, a reactivation of thrombin and increased ischaemic reactions have been described [42]. The concomitant use of inogatran and aspirin did not lead to potentiation of anticoagulant effects [43].

\section{Orally Active Thrombin Inhibitors}

\section{Melagatran (Ximelagatran)}

$\mathrm{H} 376 / 95$, the prodrug of melagatran, is a small molecule (molecular weight $474 \mathrm{D}$ ) with a bioavailability of about 20\%. The molecule is absorbed within 15-30 min, the highest melagatran plasma levels are reached within $1-2 \mathrm{~h}$.

In the METHRO II-study melagatran (24 mg) was compared with dalteparin in 1,876 patients with total knee or hip replacement. In both patient groups, melaga- 
tran was significantly more effective than dalteparin. The thrombosis incidence was almost halved in patients with total hip replacement or total knee replacement [44, 45]. Melagatran is presently being investigated in several further large clinical trials. One of the most interesting questions is whether thrombin inhibitors will be more effective or as effective as vitamin $\mathrm{K}$ antagonists with less bleeding complications.

\section{Thrombin Inhibitors in the Treatment of Heparin-Induced Thrombocytopenia}

Heparin-induced thrombocytopenia is observed in some patients during the first days of heparin treatment. Their platelet count normalizes after a few days under continued heparin administration. This phenomenon is not antibody related. It also has been named HIT type I (HIT I) or heparin-associated thrombocytopenia type I (HAT I).

Heparin-induced thrombocytopenia type II (HIT II) is triggered by an immune response to heparin. HIT II with thrombotic complications is frequently named HITT or HITTS. However, many authors use the expression 'HIT' for all types of heparin-induced thrombocytopenia with and without thrombotic complications.

For the diagnosis of HIT II, a reduction of platelet count, especially during days 3-21 after onset of heparin treatment, and clinical symptoms are more important than laboratory tests. The frequency of HIT II in different patient groups is not well established. Frequencies of 2$5 \%$ of all heparin-treated patients have been described [46-48], but in prospective trials on the treatment of deep venous thrombosis and also in patients undergoing vascular surgery lower percentages have been reported [49$52]$.

HIT II has been observed in medically and surgically treated adults, during pregnancy and in newborns [53, 54]. The most dramatic and dangerous clinical complications of HIT II are venous and/or arterial thromboses. Patients with HIT-II-associated thrombosis have been reported to have a mortality of $25-30 \%$ and an amputation rate of up to $25 \%$ [54].

The pathophysiological process of HIT II is associated with the generation of antibodies which bind to a complex of heparin coupled with peptides and proteins on platelet and endothelial cell surfaces [55-62]. The currently accepted hypothesis of the pathophysiology of HIT II is based on the development of an IgG antibody to the heparin-PF4 complex that also recognizes the FcyRIIA recep- tor on platelets. Binding of this complex causes platelet aggregation and thrombin generation. This concept is probably incomplete because the interactions between endothelium and antibodies are still not fully understood. The antibodies are not heparin specific and have been shown to react with low molecular weight heparins and dermatans [63, 64]. Endothelial cells are probably involved in the mechanism via binding of the antibody to glycosaminoglycans on the cell surface [57, 61, 62] but also to other endothelial epitopes. Damaged endothelial cells probably are the starting point for thrombotic complications.

\section{Heterogeneity of HIT II Patients}

Patients with HIT II show a large variation of clinical and laboratory symptoms. They may have a fall in platelet count with a positive antibody test with a very good prognosis if heparin is discontinued.

Patients with thrombotic complications may have been treated with heparin for several reasons. They may have already existing thrombosis, they may have a fresh thrombotic complication and the diagnosis of HIT II may have been made after several thrombotic complications in a late stage with a very poor prognosis. In addition, prognosis also depends on underlying diseases. Because of this wide variation, general statements on mortality are misleading.

\section{'Prophylaxis'}

If heparin-induced thrombocytopenia type II is suspected based on a fall in platelet count which cannot be otherwise explained and before clinical symptoms appear, heparin should immediately be discontinued and a prophylactic treatment against high-risk thrombosis should be started. There is no consensus as to the optimum prophylactic regimen to prevent imminent thromboses. Early discontinuation of heparin alone does not affect the thrombotic event rate, although early recognition may improve mortality [54]. But since early discontinuation of heparin treatment and an early switch to alternative anticoagulation are likely to prevent thrombotic complications and to reduce mortality, this kind of prophylaxis is clearly recommended.

\section{General Management}

Patients with HIT II and documented clinical thrombosis have a clear indication for anticoagulation and should be treated with danaparoid (Orgaran $\AA$ ) or a thrombin inhibitor monitored to obtain therapeutic aPTT levels. A coumarin-derivative may be initiated if
4

Pathophysiol Haemost Thromb 2002;32(suppl 3):1-8
Breddin 
the thrombin inhibitor has been given for 4-7 days. Small doses of the vitamin $\mathrm{K}$ antagonist should be used initially and the thrombin inhibition should be continued until therapeutic levels of the vitamin $\mathrm{K}$ antagonist are documented [38, 64, 65]. Among other treatment modalities, two anticoagulants are used in Europe: Orgaran and the thrombin inhibitor hirudin (lepirudin). In addition, argatroban has been released in the US for this indication.

For prophylactic treatment of HIT II patients, a thrombin inhibitor can be initiated with low level of anticoagulation until the thrombocytopenia resolves [34].

\section{Hirudin}

Hirudin (lepirudin, Refludan ${ }^{\circledR}$ ) has been approved for the treatment of thrombosis in patients with HIT II in the USA and Germany. Hirudin does not cross-react with heparin antibodies as shown by in vitro data and successful treatment of HIT II patients [66-68]. Two multi-center trials on lepirudin have been published and have demonstrated a statistically significant reduction in the primary efficacy endpoint assessed by an overall composite index (new thrombosis, amputation and death) $[69,70]$ in comparison with historic controls. Results on lepirudin treatment in HIT II patients have also been published recently [71, 72].

There are problems with hirudin treatment. Because the drug is renally excreted, hirudin accumulates in patients with renal insufficiency, a dose reduction is often necessary and monitoring with dose modifications becomes difficult $[73,74]$.

Another issue is the production of lepirudin-specific antibodies. Around $40 \%$ of patients develop antibodies against the drug. Furthermore, an investigation of data from two prospective multicenter studies of lepirudin in HIT type II patients revealed that the anticoagulant effect of lepirudin was enhanced in about $45 \%$ of the patients in whom such antibodies were detected [75]. In an investigation of anti-hirudin antibody isotypes in 23 patients with HIT type II treated with lepirudin, 13 patients (56\%) developed anti-hirudin antibodies of at least one isotype [75].

In conclusion, the potential for an antibody response complicates the management of the anticoagulant activity of lepirudin.

\section{Argatroban}

Argatroban was approved in June 2000 in the US for the prophylaxis and treatment of thromboses in patients with HIT type II. Efficacy and safety in this indication were demonstrated, in one historically controlled pivotal study and one new follow-on supportive study [39].

\section{Orgaran}

The low molecular weight heparinoid (danaparoid) Orgaran is a mixture of nonheparin polysulfated glycosaminoglycans (heparan sulfate, dermatan sulfate, chondroitin sulfate, low molecular weight heparin). Similar to heparin in structure, danaparoid differs from heparin in its degree of sulfation and molecular weight.

In vitro studies using HIT-II-positive sera showed a cross-reaction in 18 versus $100 \%$ for heparin [34]. Danaparoid has been approved for the prophylaxis of thrombosis after hip replacement surgery. It was used for many years off-label for anticoagulation in HIT II-patients [7679] but is now approved for the treatment of HIT IIpatients in Europe. Disadvantages of danaparoid are difficulties in monitoring, lack of well-established dosing guidelines [80], possibly increased postoperative bleeding [81] and the possibility of cross-reactions leading to a symptomatology similar to HIT II [78].

\section{References}

1 Markwardt F: Coagulation inhibitors from animals feeding on blood. Rev Ibero Amer Thromb Hemost 1994; 7:225-231.

2 Markwardt F: Die Isolierung und chemische Charakterisierung des Hirudins. Hoppe-Seyler's Z Physiol Chem 1957;308:147-156.

3 Fox I, Dawson A, Loynds P, Eisner J, Findlen K, Lenn E, Hanson D, Mant T, Wagner J, Maraganore J: Anticoagulant activity of hirulog, a direct thrombin inhibitor in humans. Thromb Haemost 1993;69:157-163.
4 Maraganore JM, Bourdon P, Jablonski J, Ramachandran L, Fenton JW: Design and characterization of hirulogs: A novel class of bivalent peptide inhibitors of thrombin. Biochemistry 1990;29:7095-7101.

5 Nowak G, Bucha E: Quantitative determination of hirudin in blood and body fluids. Semin Thromb Haemost 1996;22:197-202.
6 Pötzsch B, Madlener K, Seelig C, Riess CF, Greinacher A, Müller-Berghaus G: Monitoring of r-hirudin anticoagulation during cardiopulmonary bypass - assessment of the whole blood ecarin clotting time. Thromb Haemost 1997; 77:920-925.

7 Schenk JF, Glusa E, Radziwon P, Markwardt F, Breddin HK: A recombinant hirudin (IKHIR02) in healthy volunteers. I. Effects on coagulation parameters and bleeding time. Haemostasis 1996;26:140-149.
Antithrombotic Therapy with Thrombin Inhibitors
Pathophysiol Haemost Thromb 2002;32(suppl 3):1-8 
8 Van den Bos A, Deckers JW, Heyndrickx GR, Laarman GJ, Suryapranata H, Zijlstra F, Close P, Rijnierse JMM, Buller HR, Serruys PW Safety and efficacy of recombinant hirudin (CGP 39 393) versus heparin in patients with stable angina undergoing coronary angioplasty. Circulation 1993;88:2058-2066.

9 Antman EM for the TIMI 9A investigators: Hirudin in acute myocardial infarction: Safety report from the thrombolysis and thrombin inhibition in myocardial infarction (TIMI) 9A trial. Circulation 1994;90:1624-1630.

10 Cannon CP, McCabe CH, Henry TD, Schweiger MC, Gibson RS, Mueller HS, Becker RC, Kleiman NS, Haugland M, Anderson JL, Sharaf BL, Edwards SJ, Rogers WJ, Williams DO, Braunwald E: A pilot trial of recombinant desulfatohirudin compared with heparin in conjunction with tissue type plasminogen activator and aspirin for acute myocardial infarction: Results of the thrombolysis in myocardial infarction (TIMI) 5 trial. J Am Coll Cardiol 1994, 23:993-1003.

11 Lidon RM, Théroux P, Lesperance J, Adelman B, Bonan R, Duval, D, Levesque J: A pilot, early angiographic patency study using a direct thrombin inhibitor as adjunctive therapy to streptokinase in acute myocardial infarction. Circulation 1994;89:1567-1572.

12 The Global Use of Strategies to Open Occluded Coronary Arteries (GUSTO) IIa-investigators. Randomized trial of intravenous heparin versus recombinant hirudin for acute coronary syndromes. Circulation 1994;90:1631-1637.

13 Organisation to Assess Strategies for Ischemic Syndromes (OASIS-2) Investigators: Effects of recombinant hirudin (lepirudin) compared with heparin on death, myocardial infarction, refractory angina, and revascularisation procedures in patients with acute myocardial ischaemia without ST elevation: A randomised trial. Lancet 1999;353:429-438.

14 Herrman JPR; Simon R, Umans VAWM Peerboom PF, Keane D, Runierse JJMM, Bach D, Kobi P, Kerry R, Close P, Deckers JW, Serruys PW: Evaluation of recombinant hirudin (CGP 39 393/registered REVASC) in the prevention of restenosis after percutaneous transluminal coronary angioplasty. Rationale and design of the Helvetica trial, a multicentre randomized double blind heparin controlled study. Eur Heart J 1995; 16:56-62.

15 Antman EM for the TIMI 9B investigators: Hirudin in acute myocardial infarction. Thrombolysis and thrombin inhibition in myocardial infarction (TIMI) 9B trial. Circulation 1996;94:911-921.

16 The Global Use of Strategies to Open Occluded Coronary Arteries (GUSTO) II-investigators: A comparison of recombinant hirudin with heparin for the treatment of acute coronary syndromes. N Engl J Med 1996;335:775-782.
17 Neuhaus KL, von Essen R, Tebbe U, Jessel A, Heinrichs H, Mäurer W, Döring W, Harmjanz D, Kötter V, Kalhammer E, Simon H, Horacek T: Safety observations from the pilot phase of the randomized r-hirudin for improvement of thrombolysis (HIT-III) study. A study of the Arbeitsgemeinschaft Leitender Kardiologischer Krankenhausärzte (ALKK). Circulation 1994:90:1638-1642.

18 Neuhaus KL, Moloek GP, Zeymer U, Tebbe U, Wegscheider K, Schroder R, Camez A, Laarman GJ, Grollier GM, Lok DJ, Kuckuck H, Lazarus P: Recombinant hirudin (lepirudin) for the improvement of thrombolysis with streptokinase in patients with acute myocardial infarction: Results of the HIT-4 trial. J Am Coll Cardiol 1999;34:966-973.

19 Von Essen R, Zeymer U, Tebbe U, Jessel A, Kwasny H, Mateblowski M, Niederer W, Wagner J, Maurer W, von Leitner ER, Haerten K, Roth M, Neuhaus KL: HBW 023 (recombinant hirudin) for the acceleration of thrombolysis and prevention of coronary reocclusion in acute myocardial infarction: Results of a dosefinding study (HIT-II) by the Arbeitsgemeinschaft Leitender Kardiologischer Krankenhausärzte. Coron Artery Dis 1998;9:265-272.

20 Breddin HK, Radziwon P, Eschenfelder V, Müller-Peltzer H, Esslinger HU: PEG-hirudin and acetylsalicylic acid show a strong interaction on bleeding time. Ann Haematol 1996; 72(suppl I):A 53

21 Bang CJ, Riedel B, Talstad I, Berstad A: Interaction between heparin and acetylsalicylic acid on gastric mucosal and skin bleeding in humans. Scand J Gastroenterol 1992;27:489_ 494.

22 Eriksson BI, Ekman S, Kälebo P, Zachrisson B, Bach D, Close P: Prevention of deep-vein thrombosis after total hip replacement: Direct thrombin inhibition with recombinant hirudin, CGP 39393. Lancet 1996;347:635-639.

23 Eriksson BI, Joergensen PW, Kälebo P, Mouret $\mathrm{P}$, Rosencher N, Bösch P, Baur M, Ekman S, Bach D, Linbratt S, Close P: A comparison of recombinant Hirudin with a low molecular weight heparin top prevent thromboembolic complications after total hip replacement. N Engl J Med 1997;337:1329-1335.

24 Parent F, Bridey F, Dreyfus M, Musset D, Grimon G, Duroux P, Meyer D, Simoneau G: Treatment of severe venous thromboembolism with intravenous hirudin (HBW 023): An open pilot study. Thromb Haemost 1993;70:386388.

25 Schiele F, Vuillemenot A, Kramarz P, Kieffer Y, Soria J, Soria C, Camez A, Mirshahi MC, Bassand JP: A pilot study of subcutaneous recombinant hirudin (HBW 023) in the treatment of deep vein thrombosis. Thromb Haemost 1994; 71:558-562

26 Kong DF, Topol EJ, Bittl JA, White HD, Theroux P, Hasselblad V, Califf RM: Clinical outcomes of bivalirudin for ischemic heart disease. Circulation 1999;100:2049-2053.
27 Maraganore JM, Bourdon P, Jablonski J, Ramachandran L, Fenton JW: Design and characterization of hirulogs: A novel class of bivalent peptide inhibitors of thrombin. Biochemistry 1990;29:7095-7101.

28 Piana RN, Ahmed WH, Chaitman B, Ganz P, Kinlay S, Strony J, Adelman B, Bittl JA: Effect of transient abrupt vessel closure during otherwise successful angioplasty for unstable angina on clinical outcome at six months. Hirulog Angioplasty Study Investigators. J Am Coll Cardiol 1999;33:73-78.

29 Théroux P, Pérez-Villa F, Waters D, Lespérance J, Shabani F, Bonan R: Randomized couble-blind comparison of two doses of hirulog with heparin as adjunctive therapy to streptokinase to promote early patency of the infarctrelated artery in acute myocardial infarction. Circulation 1995;91:2132-2139.

30 Topol EJ, Bonan R, Jewitt D, Sigwart U, Kakkar VV, Rothman M, de Bono D, Ferguson J, Willerson JT, Strony J, Ganz P, Cohen MD, Raymond R, Fox I, Maraganore J, Adelman B: Use of a direct antithrombin, hirulog, in place of heparin during coronary angioplasty. Circulation 1993;87:1622-1629.

31 Sharma GVRK, Lapsley DE, Vita JA, Sharma S, Coccio E, Adelman B, Loscalzo J: Safety and efficacy of hirulog in patients with unstable angina. Circulation 1992;86:I-386.

32 Ginsberg JS, Nurmohamed MT, Gent M, MacKinnon B, Sicurella J, Brill-Edwards P, Levine MN, Panju AA, Powers P, Stevens P, Turpie AGG, Weitz J, Buller HR, ten Cate JW, Neemeh J, Adelman B, Fox I, Maraganore J, Hirsh $\mathrm{J}$ : Use of hirulog in the prevention of venous thrombosis after major hip or knee surgery. Circulation 1994;90:2385-2389.

33 White H: The Hirulog and Early Reperfusion or Occlusion (HERO)-2 Trial Investigators. Thrombin-specific anticoagulation with bivalirudin versus heparin in patients receiving fibrinolytic therapy for acute myocardial infarction: The HERO-2 randomised trial. Lancet 2001; 358:1988-1963.

34 Walenga JM, Fasanella AR, Iqbal O, Hoppensteadt DA, Ahmad S, Wallis DE, et al: Coagulation laboratory testing in patients treated with argatroban. Semin Thromb Hemost 1999; 25(suppl 1):61-66.

35 Lewis BE, Ferguson JJ, Grassman ED, Fareed J, Walenga JM, Joffroin JL, et al: Successful coronary intervention performed with argatroban anticoagulation in patients with heparininduced thrombocytopenia and thrombosis syndrome. J Invas Cardiol 1996;8:410-417.

36 Lewis BE, Iaffaldano R, McKiernan TL, Rao L, Donkin J, Walenga JM: Report of successful use of argatroban as an alternative anticoagulant during coronary stent implantation in a patient with heparin-induced thrombocytopenia and thrombosis syndrome. Cathet Cardiovasc Diagn 1996;38:206-209. 
37 Lewis BE, Rangel Y, Fareed J: The first report of successful carotid stent implant using argatroban anticoagulation in a patient with heparin-induced thrombocytopenia and thrombosis syndrome. A case report. Angiology 1998;49: 61-67.

38 Lewis BE, Walenga JM, Wallis DE: Anticoagulation with Novastan ${ }^{\circledR}$ (argatroban) in patients with heparin-induced thrombocytopenia and thrombosis syndrome. Semin Thromb Hemost 1997;23:197-202.

39 Lewis BE, Wallis DE, Berkowitz SD, Matthai WH, Fareed J, Walenga JM, et al: Argatroban anticoagulant therapy in patients with heparininduced thrombocytopenia. Circulation 2001; 103:1838-1843.

40 Suzuki S, Sakamoto S, Koide M, Matsuo M, Fuji K, Matsuo T: Effective anticoagulation by argatroban during coronary stent implantation in a patient with heparin-induced thrombocytopenia. Thromb Res 1997;88:499-502.

41 Thrombin inhibition in myocardial ischaemia (TRIM) study group: A low molecular weight, selective thrombin inhibitor, inogatran, vs. heparin in unstable coronary artery disease in 1209 patients. A double-blind, randomized, dosefinding study. Eur Heart J 1997;18:1416-1425.

42 Andersen $\mathrm{K}$, Dellborg M, Emanuelsson $\mathrm{H}$ Grip L, Swedberg K: Thrombin inhibition with inogatran for unstable angina pectoris: Evidence for reactivated ischaemia after cessation of short-term treatment. Coron Artery Dis 1996;7:673-681.

43 Chen LY, Nichols WW, Mattsson C, TegerNilson AC, Wallin R, Saldeen TG, Mehta JL: Aspirin does not potentiate effect of suboptimal dose of the thrombin inhibitor inogatran during coronary thrombolysis. Cardiovasc Res 1995;30:866-874

44 Eriksson BI, Ögren M, Agnelli G, Cohen A Dahl OE, Mouret P, Rosencher N, Eskilson C, Nylander I, Frison L: The oral direct thrombin inhibitor ximelagatran (pINN, formerly H 376/ 95) and its subcutaneous form melagatran compared with enoxaparin as thromboprophylaxis after total hip or total knee replacement. Thromb Haemost 2001;suppl:abstract OC1638.

45 Gustafsson D, Nystrom J, Carlsson S. Bredberg U, Eriksson U, Gyzander E, Elg M, Antonsson T, Hoffmann K, Ungell A, Sorensen H, Nagard S. Abrahamsson A, Bylund R: The direct thrombin inhibitor melagatran and its oral prodrug H 376/95: Intestinal absorption properties, biochemical and pharmacodynamic effects. Thromb Res 2001;101:171-181.

46 Aster RH: Heparin-induced thrombocytopenia and thrombosis. N Engl M Med 1995;332: 1374-1376.

47 Warkentin TE: Venous thromboembolism in heparin-induced thrombocytopenia. Curr Opin Pulm Med 2000;6:343-351.

48 Warkentin TE, Levine MN, Hirsh J, Horsewood P, Roberts RS, Gent M, Kelton JG: Heparin-induced thrombocytopenia in patients treated with low-molecular-weight heparin of unfractionated heparin. N Engl J Med 1995; 332:1330-1335.
49 Harenberg J, Schmidt JA, Koppenhagen K, Tolle A, Huisman MV, Büller HR: Fixed-dose, body weight-independent subcutaneous LMW heparin versus adjusted dose unfractionated intravenous heparin in the initial treatment of proximal venous thrombosis. Thromb Haemost 2000;83:652-656.

50 Kirchmaier CM, Wolf H, Schäfer H, Ehlers B, Breddin HK: Efficacy of a low molecular weight heparin administered intravenously or subcutaneously in comparison with intravenous unfractionated heparin in the treatment of deep venous thrombosis. Int Angiol 1998;17: 135-145.

51 Lindhoff-Last E, Eichler P, Stein M, Plagemann J, Gerdsen F, Wagner R, Ehrly AM, Bauersachs R: A prospective study on the incidence and clinical relevance of heparin-induced antibodies in patients after vascular surgery. Thromb Res 2000;97:387-393.

52 Lindhoff-Last E, Nakov R, Mosch G, Breddin $\mathrm{HK}$, Bauersachs R: Incidence and clinical relevance of heparin-PF4-antibodies in 1137 patients with deep venous thrombosis treated with UFH or LMWH. Ann Hematol 2000; 79(suppl I):A3

53 Greinacher A, Eckhardt T, Mussmann J, Mueller-Eckhardt C: Pregnancy complicated by heparin associated thrombocytopenia management by a prospective in vitro selected heparinoid (ORG 10172). Thromb Res 1993;71: 123-126.

54 Wallis DE, Workman DL, Lewis BE, Steen L, Pifarré R: Failure of early heparin cessation as treatment for heparin-induced thrombocytopenia. Am J Med 1999;106:629-635.

55 Amiral J, Bridey, F, Dreyfus M, Vissoc AM, Fressinaud E, Wolf M, et al: Platelet factor 4 complexed to heparin is the target for antibodies generated in heparin-induced thrombocytopenia. Thromb Haemost 1992;68:95-96.

56 Brandt JT, Isenhart CE, Osborne JM, Ahmed A, Anderson CL: On the role of platelet FcyRIIA phenotype in heparin-induced thrombocytopenia. Thromb Haemost 1995;74:15641572.

57 Cines DB, Tomaski A, Tannenbaum S: Immune endothelial-cell injury in heparin associated thrombocytopenia. N Engl J Med 1987; 316:581-589.

58 Greinacher A, Michels I, Liebenhoff U, Presek $\mathrm{P}$, Mueller-Eckhardt C: Heparin-associated thrombocytopenia: Immune complexes are attached to the platelet membrane by the negative charge of highly sulphated oligosaccharides. Br J Haematol 1993;84:711-716.

59 Greinacher A, Pötzsch B, Amiral J, Dummel V, Eichner A, Mueller-Eckhardt C: Heparinassociated thrombocytopenia: Isolation of the antibody and characterization of a multimolecular PF-4 heparin complex as the major antigen. Thromb Haemost 1994;71:247-251.

60 Kelton JG, Smith JW, Warkentin TE, Hayward CPM, Denomm GA, Horsewood P: Immunoglobulin $\mathrm{G}$ from patients with heparininduced thrombocytopenia binds to a complex of heparin and platelet factor 4. Blood 1994;83: 3232-3239.
61 Visentin GP, Ford SE, Scott JP, Aster RH: Antibodies from patients with heparin-induced thrombocytopenia/thrombosis are specific for platelet factor 4 complexed with heparin or bound to endothelial cells. J Clin Invest 1994; 93:81-88.

62 Warkentin TE, Hayward CP, Boshkov LK, Santos AV, Sheppard JI, Bode AP, Kelton JG: Sera from patients with heparin-induced thrombocytopenia generate platelet derived microparticles with procoagulant activity: An explanation for the thrombotic complications of heparin-induced thrombocytopenia. Blood 1994;84:3691-3699.

63 Greinacher A, Feigl M, Mueller-Eckhardt C: Crossreactivitiy studies between sera of patients with heparin-associated thrombocytopenia and a new low molecular weight heparin, reviparin. Thromb Haemost 1994;72:644645

64 Walenga JM, Lewis BE, Hoppensteadt DA, Fareed J, Bakhos M: Management of heparininduced thrombocytopenia and heparin-induced thrombocytopenia and thrombosis syndrome. Clin Appl Thromb Hemost 1997; 3(suppl 1):53-63.

65 Wallis DE, Quintos R, Wehrmacher W, Messmore $\mathrm{H}$ : Safety of warfarin anticoagulation in patients with heparin-induced thrombocytopenia. Chest 1999;116:1333-1338

66 Olbrich K, Wiersbitzky M, Wacke W, Eichler P, Zinke H, Schwock M, Mox B, Kraatz G, Motz W, Greinacher A: Atypical heparin-induced thrombocytopenia complicated by intracardiac thrombus, effectively treated with ultra-low-dose rt-PA lysis and recombinant hirudin (lepirudin). Blood Coagul Fibrinolysis 1998;9:273-277.

67 Walenga JM, Jeske WP, Wallis DE, Bakhos M, Lewis BE, Leya F, et al: Clinical experience with combined treatment of thrombin inhibitors and GP IIb/IIIa-inhibitors in patients with HIT. Semin Thromb Hemost 1999;25(suppl 1):77-81.

68 Walenga JM, Lewis BE, Jeske WP, Leya F, Wallis DE, Bakhos M, et al: Combined thrombin and platelet inhibition treatment for HIT patients. Hämostaseologie 1999;19:128-133.

69 Greinacher A, Eichler P, Lubenow N, Kwasny H, Luz M: Heparin-induced thrombocytopenia with thromboembolic complications: Metaanalysis of 2 prospective trials to assess the value of parenteral treatment with lepirudin and its therapeutic aPTT range. Blood 2000;96: 846-851.

70 Greinacher A, Janssens U, Berg G, Kwasny H, Kemkes-Matthes B, Eichler P, Volpel H, Potzsch B, Luz M: Lepirudin (recombinant hirudin) for parenteral anticoagulation in patients with heparin-induced thrombocytopenia. Heparin-Associated Thrombocytopenia Study (HAT) investigators. Circulation 1999; 100:587-593.

71 Schneider T, Heuer B, Deller A, Boesken WH: Continuous haemofiltration with r-hirudin (lepirudin) as anticoagulant in a patient with heparin induced thrombocytopenia (HIT II). Wien Klin Wochenschr 2000;112:552-555.
Antithrombotic Therapy with Thrombin Inhibitors
Pathophysiol Haemost Thromb 2002;32(suppl 3):1-8 
72 Shah AC, Genoni M, Neiderhauser U, Maloigne M, Turina M: R-hirudin (lepirudin, refludan) as an alternative anticoagulant in heparin-induced thrombocytopenia during cardiopulmonary bypass connection. Schweiz Med Wochenschr 2000;130:896-899.

73 Davenport A: Management of heparin-induced thrombocytopenia during continuous renal replacement therapy. Am J Kidney Dis 1998;32: E3.

74 Fisher KG, van de Loo A, Bohler J: Recombinant hirudin (lepirudin) as anticoagulant in intensive care patients treated with continuous hemodialysis. Kidney Int 1999;56(suppl 72): S46-50.
75 Eichler P, Friesen HJ, Lubenow N, Jaeger B, Greinacher A: Antihirudin antibodies in patients with heparin-induced thrombocytopenia treated with lepirudin: Incidence, effects on aPTT, and clinical relevance. Blood 2000;96: 2373-2378.

76 Gillis S, Merin G, Zahger D, Deeb M, Drenger B, Hyam E, Eldor A: Danaparoid for cardiopulmonary bypass in patients with previous heparin-induced thrombocytopenia. Br J Haematol 1997;98:657-659.

77 Gitlin SD, Deeb GM, Yann C, Schmaier AH: Intraoperative monitoring of danaparoid sodium anticoagulation during cardiovascular operations. J Vasc Surg 1998;27:568-575.
78 Magnani HN: Heparin-induced thrombocytopenia (HIT): An overview on 230 patients treated with orgaran (Org 10172). Thromb Haemost 1993;70:554-561.

79 Magnani HN: Einsatz von Danaparoid (Orga$\left.\operatorname{ran}^{\circledR}\right)$ zur Antikoagulation bei kardiovaskulären Operationen. VASA 2000;29(suppl 56): D02.

80 Brieger DB, Mak KH, Kottke-Marchant K, Topol EJ: Heparin-induced thrombocytopenia. J Amer Coll Cardiol 1998;31:1449-1459.

81 Chong BH, Ismail F, Cade J, Gallus AS, Gordon S, Chesterman CN: Heparin-induced thrombocytopenia: Studies with a new low molecular weight heparinoid, Org 10172. Blood 1989;73:1592-1596. 